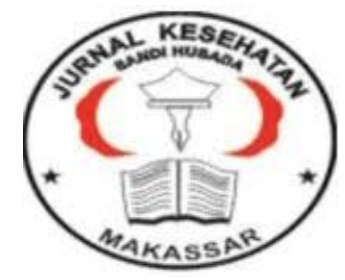

Jurnal Ilmiah Kesehatan Sandi Husada

hhttps://akper-sandikarsa.e-journal.id/JIKSH

Volume 9, Nomor 2, Desember 2020, pp 713-718

p-ISSN: 2354-6093 dan e-ISSN: 2654-4563

DOI: $10.35816 /$ jiskh.v10i2.390

\title{
Dampak Debu Organik Serbuk Kayu Terhadap Penyakit Paru Obstruktif Akibat Kerja
}

Impact of Organic Wood Dust on Occupational Obstructive Lung Disease

Made Sherly Armiyanti

Fakultas Kedokteran, Universitas Lampung

\begin{tabular}{l}
\hline \multicolumn{1}{c}{ Artikel info } \\
\hline \\
Artikel history: \\
Received; Juli 2020 \\
Revised: Agustus 2020 \\
Accepted; Agustus 2020
\end{tabular}

\begin{abstract}
Abstrak
Latar Belakang: Dampak pencemaran udara ini dapat terjadi pada berbagai aspek kehidupan. Pekerja yang terpajan debu memiliki risiko untuk mengalami keluhan kesehatan dan penyakit, baik penyakit infeksi maupun non infeksi (kanker).Tujuan: mengetahui lebih lanjut tentang dampak serbuk kayu organic yang mengakibatkan terjadinya penyakit paru obstruktif akibat kerja. Metode: Metode yang digunakan oleh penulis adalah studi literatur dari berbagai jurnal nasional maupun internasional. Metode ini digunakan dengan tujuan menyajikan, menambah pengetahuan dan pemahaman mengenai topik yang dibahas dengan meringkas materi yang telah diterbitkan serta memberikan informasi fakta atau analisis baru dari tinjauan literatur yang relevan kemudian membandingkan hasil tersebut dalam artikel. Hasil: Debu organik serbuk kayu dapat menyebabkan terjadinya penyakit paru obstruktif pada pekerja yang terpapar debu tersebut. Kesimpulan: Debu organik serbuk kayu dapat menyebabkan terjadinya penyakit paru obstruktif pada pekerja yang terpapar debu tersebut. Tedapat penelitian yang mengatakan bahwa salah sau faktor terjadinya penyakit paru obstruktif akibat kerja dipengaruhi oleh banyakya kadar debu ditempat kerja serta lamanya paparan. Untuk itu penggunaan APD seperti masker harus diperhatikan pada saat bekerja.
\end{abstract}

\section{Abstract.}

Background: The impact of air pollution can occur in various aspects of life. Workers exposed to dust have a risk of experiencing health complaints and diseases, both infectious and non-infectious (cancer). Purpose: to find out more about the impact of organic wood dust which causes occupational obstructive pulmonary disease. Method: The method used by the author is a literature study from various national and international journals. This method is used with the aim of presenting, increasing knowledge and understanding of the 
topics discussed by summarizing material that has been published and providing factual information or new analysis from relevant literature reviews and then comparing the results in the article. Result: Wood dust organic dust can cause obstructive pulmonary disease in workers exposed to the dust. Conclusion: Wood dust organic dust can cause obstructive pulmonary disease in workers exposed to the dust. There are studies that say that one of the factors in the occurrence of occupational obstructive pulmonary disease is influenced by the amount of dust in the workplace and the length of exposure. For this reason, the use of PPE such as masks must be considered at work.

Keywords:
Sawdust;
Pulmonary obstructive;
Coresponden author:

Email: madesherly20@gmail.com

artikel dengan akses terbuka dibawah lisensi CC BY 4.0

\section{Pendahuluan}

Salah satu industri yang berkembang pesat di Indonesia adalah industry pengolahan kayu, hal ini berkaitan dengan konsumsi hasil hutan yang mencapai 33 juta m3 per tahun. Namun, hal tersebut menimbulkan dampak negatif yaitu timbulnya pencemaran udara oleh debu yang dihasilkan dari proses pengolahan atau hasil industri tersebut (Suryani, 2005). Debu adalah partikel padat yang berasal dari pemecahan suatu bahan, baik yang berasal dari kegiatan manusia maupun proses alam (Mukono, 2003). Debu kayu tersusun dari senyawa lignin, holo-selulosa (selulosa dan hemi- selulosa), dan senyawa karbohidrat dalam jumlah yang rendah. Oleh sebab itu, debu kayu digolongkan ke dalam debu organik (Suma'mur, 2009).

Debu kayu memiliki sifat kurang reaktif tetapi dapat menyebabkan reaksi alergik dan gangguan kesehatan pada pekerja yang terpajan. Besarnya gangguan kesehatan dipengaruhi oleh faktor ukuran partikel debu, lama pajanan, dan faktor individual (Mirza, 2010). Keberadaan debu di udara akan mengakibatkan terjadinya pencemaran udara. Pencemaran udara adalah terdapatnya bahan, zat, atau komponen lain di dalam udara yang menyebabkan perubahan susunan udara. Dampak pencemaran udara ini dapat terjadi pada berbagai aspek kehidupan (Wardhana, 2004). Debu apabila terdapat dalam jumlah yang berlebihan untuk jangka waktu yang lama, dapat menyebabkan kerusakan patologis pada manusia. Penumpukan dan pergerakan debu pada saluran nafas dapat menyebabkan peradangan jalan nafas. Peradangan ini dapat mengakibatkan penyumbatan jalan nafas, sehingga dapat menurunkan kapasitas paru (American Thoracic Society, 1995).

Pekerja yang terpajan debu memiliki risiko untuk mengalami keluhan kesehatan dan penyakit, baik penyakit infeksi maupun non infeksi (kanker). Keluhan pernapasan merupakan masalah kesehatan yang paling banyak dijumpai dalam industri kayu. Selain keluhan pernapasan, dampak pajanan debu terhadap kesehatan yang sering dilaporkan adalah dermatitis, gangguan fungsi paru, dan beberapa jenis kanker pada saluran pernapasan. Mikroorganisme yang terdapat pada kayu juga dapat menyebabkan terjadinya keluhan dan gangguan kesehatan. Dampak paparan debu yang terus menerus dapat menurunkan faal paru berupa obstruktif (Irjayanti, dkk., 2012). 
Obstruktif adalah penurunan kecepatan aliran ekspirasi (ekspiratory flow) (Hicks GH, 2000). Penyakit Paru Obstruktif Kronik (PPOK) merupakan penyebab utama dari morbiditas di seluruh dunia yang ditandai dengan keterbatasan aliran udara yang progesif dan sebagian besar yang irreversible (Macnee, 2006). Gejala klinis pada PPOK berupa batuk, produksi sputum yang meningkat dan adanya gejala sesak. Beberapa faktor risiko sebagai penyebab PPOK yaitu merokok, usia, paparan asap populasi lingkungan atau pekerjaan, alpha-1 antitripsin, riwayat infeksi pernapasan dan riwayat keluarga yang mengalami PPOK (Stephen and yew, 2008). Berdasarkan latar belakang tersebut penulis bermaksud melakukan tinjauan literature untuk mengetahui dampak debu organik serbuk kayu terhadap penyakit paru obstruktif akibat kerja

\section{Metode}

Metode yang digunakan oleh penulis adalah studi literatur dari berbagai jurnal nasional maupun internasional. Metode ini digunakan dengan tujuan menyajikan, menambah pengetahuan dan pemahaman mengenai topik yang dibahas dengan meringkas materi yang telah diterbitkan serta memberikan informasi fakta atau analisis baru dari tinjauan literatur yang relevan kemudian membandingkan hasil tersebut dalam artikel.

\section{Hasil Dan Pembahasan}

Debu kayu adalah partikel-partikel zat padat (kayu) yang dihasilkan oleh kekuatankekuatan alami atau mekanik seperti pada pengolahan, penghancuran, pelembutan, pengepakan yang cepat, peledakan dan lain-lain dari bahan-bahan organik maupun anorganik misalnya kayu, biji logam dan arang batu (Sinaga, 2019). Debu kayu memiliki sifat kurang reaktif tetapi dapat menyebabkan reaksi alergik dan gangguan kesehatan pada pekerja yang terpajan. Besarnya gangguan kesehatan dipengaruhi oleh faktor ukuran partikel debu, lama pajanan, dan faktor individual (Mirza, 2010). Kadar debu di lingkungan kerja juga dipengaruhi oleh suhu dan kelembapan. Suhu yang terlalu tinggi dapat meningkatkan penyebaran debu di lingkungan kerja. Sedangkan kelembapan yang tinggi merupakan kondisi yang optimal bagi mikroorganisme untuk dapat berkembang biak (Sastrawijaya, 2009).

Debu kayu dalam konsentrasi rendah bila dihisap oleh manusia terus menerus dalam jangka waktu yang lama dapat menimbulkan kelainan pada saluran napas yang berupa restriksi, obstruksi ataupun kombinasi. Pemaparan. Debu organik pada umumnya akan menyebabkan obstruksi pada saluran pernapasan yang ditunjukkan dengan penurunan \% VEP1/KVP. Pekerja yang terpapar debu kayu secara kontiniu pada usia 15 sampai dengan 25 tahun akan terjadi penurunan kemampuan kerja, usia 25 sampai dengan 35 tahun timbul batuk produktif dan penurunan VEP 1 ( volume ekspirasi paksa 1 detik, usia 45 sampai dengan 55 tahun terjadi sesak dan hipoksemia, usia 55 sampai dengan 65 tahun terjadi cor pulmonal sampai kegagalan pernapasan dan kematian, hal ini dapat dideteksi dengan pemeriksaan spirometer (Sinaga, 2019). Pekerja yang terpajan debu memiliki risiko untuk mengalami keluhan kesehatan dan penyakit, baik penyakit infeksi maupun non infeksi (kanker). Keluhan pernapasan merupakan masalah kesehatan yang paling banyak dijumpai dalam industri kayu. Selain keluhan pernapasan, dampak pajanan debu terhadap kesehatan yang sering dilaporkan adalah dermatitis, gangguan fungsi paru, dan beberapa jenis kanker pada saluran pernapasan. Mikroorganisme yang terdapat pada kayu juga dapat menyebabkan terjadinya keluhan dan gangguan kesehatan (Irjayanti, dkk., 2012).

Keluhan pernapasan yang terjadi dipengaruhi oleh ukuran debu. Debu yang berukuran 510 mikron akan masuk ke dalam saluran napas atas, 3-5 mikron masuk ke dalam saluran 
napas tengah, 1- 3 mikron dapat mencapai pembuluh di alveoli, 0,5-1 mikron akan menempel di alveoli, dan debu yang berukuran 0,1-0,5 akan melayang di atas alveoli (Depkes, 2014). Berbagai keluhan seperti hidung tersumbat, batuk, rinitis, dan asma juga dapat dialami oleh pekerja di industri kayu (Mirza, 2010).

Hasil penelitian Osman dan Pala (2009) menyatakan bahwa debu yang terhirup dapat menimbulkan keluhan kesehatan seperti iritasi mata, nyeri tenggorokan, dan rhinorhea. Keluhan yang dialami dapat berkembang menjadi gangguan fungsi paru bila pekerja terpajan debu dalam waktu lama (Khumaidah, 2009). Debu kayu yang masuk ke dalam saluran pernapasan menyebabkan timbulnya reaksi pertahanan non spesifik dan merangsang otot polos di sekitar jalan napas. Keadaan ini menyebabkan penyempitan saluran napas dan memicu terjadinya penurunan fungsi paru. Hal ini dapat terjadi apabila kadar debu di lingkungan kerja melebihi nilai ambang batas (Suryani, 2005).

Berdasarkan Peraturan Menteri Tenaga Kerja dan Transmigrasi Nomor 13 Tahun 2011 tentang Nilai Ambang Batas Faktor Fisika dan Faktor Kimia di Tempat Kerja menyatakan bahwa nilai ambang batas adalah standar faktor bahaya di tempat kerja sebagai kadar/intensitas rerata tertimbang waktu (time weighted average) yang dapat diterima tenaga kerja tanpa mengakibatkan penyakit atau gangguan kesehatan pada pekerja dalam melakukan pekerjaannya setiap hari dalam waktu tidak lebih dari 8 jam/hari atau 40 jam/minggu. Selain bertujuan untuk Anindya M Sholikhah dan Sudarmaji, Hubungan Karakteristik Pekerja Dan Kadar 3 melindungi pekerja, penetapan nilai ambang batas dapat digunakan sebagai pedoman dalam perencanaan proses produksi dan teknologi pengendalian bahaya yang terdapat di lingkungan kerja serta membantu menegakkan diagnosis penyakit akibat kerja.

Penelitian Tanko (2011) tentang efek debu kayu pada fungsi cardiopulmonary pekerja mebel informal juga menyebutkan bahwa paparan debu kayu pada tukang kayu dapat menyebabkan peningkatan tekanan darah arteri dan menyebabkan penurunan FVC, FEV1 (Tanko, 2011). Bahan polutan tertentu, seperti debu kayu dapat mengakibatkan obstruksi, yaitu keadaan hambatan aliran udara karena adanya sumbatan atau penyempitan saluran nafas. Iritasi yang disebabkan bahan polutan ini akan menyebabkan inflamasi bronkiolus dan alveolus. Adanya produksi mukus yang berlebih menyebabkan terjadinya sumbatan bronkiolus dan alveolus. Mukus dengan jumlah yang banyak dan kental serta menurunnya pembersihan mukosiliar dapat menyebabkan meningkatnya risiko infeksi (Ikawati, 2011).

Obstruksi adalah setiap keadaan hambatan aliran udara karena adanya sumbatan atau penyempitan saluran nafas. Sindrom perunyumbatan ini terjadi apabila kapasitas ventilasi menurun akibat menyempitnya saluran udara nafas. Restriksi ini ditandai dengan terjadinya Forced Expiratory Volume in one second (FEV1) yang lebih besar dibandingkan dengan FVC sehingga rasio FEV1/ FVC kurang dari 80\%. Hasil pemeriksaan dengan spirometri tehadap faal paru pekerja mebel pada penelitian yang dilakukan oleh Ma'rufi (2016) menunjukkan bahwa sebagian besar pekerja tidak mengalami obstruksi atau normal, yaitu sebanyak 72 pekerja dan paling sedikit mengalami obstruksi berat yaitu 3 pekerja. Proporsi pekerja yang mengalami obstruksi berat pada umur $>50$ tahun lebih tinggi dibandingkan pada kelompok umur 17-30 tahun dan 41-50 tahun. Proporsi pekerja dengan lama paparan kerja $>8$ jam lebih tinggi mengalami obstruksi berat dibandingkan dengan lama paparan kerja $<8$ jam. Proporsi pekerja yang mengalami obstruksi berat pada masa kerja $>10$ tahun lebih tinggi dibandingkan dengan masa kerja $<5$ tahun dan 610 tahun (Sholikhah, 2015).

Penelitian yang dilakukan oleh Mar'atus pada tahun 2015 menyatakan, hasil identifikasi keluhan pernapasan yang dialami oleh pekerja Unit Y menunjukkan bahwa responden 
yang mengalami keluhan pernapasan sebesar $87,67 \%$, sedangkan pekerja yang tidak mengalami keluhan pernapasan sebesar 12,33\%. Responden yang bekerja di lingkungan dengan kadar debu total maksimum yang tidak memenuhi NAB dan mengalami keluhan pernapasan sebesar 90,6\%, sedangkan responden yang bekerja di lingkungan dengan kadar debu total maksimum yang memenuhi NAB dan mengalami keluhan pernapasan sebesar 9,4\%. Responden yang bekerja di lingkungan dengan kadar debu total maksimum tidak memenuhi $\mathrm{NAB}$ dan tidak mengalami keluhan pernapasan sebesar 55,6\%, sedangkan responden yang bekerja di lingkungan dengan kadar debu total maksimum memenuhi NAB dan tidak mengalami keluhan pernapasan sebesar 44,4\%. Hasil uji Chi Square menunjukkan adanya hubungan yang signifikan antara kadar debu total dan keluhan pernapasan pada pekerja (Solikhah, 2015).

Dari hasil penelitian Suryani pada tahun 2005 di peroleh data responden yang memiliki gangguan Obstruktif 3 orang, Restriktif 12 orang, Normal 55 orang. Rata-rata kapasitas fungsi paru pekerja PT SSSWI-Wonosobo menunjukkan 92,04\% FEV1/FVC dengan standar deviasi 6,68 sedang. Analisis Faktor Risiko nilai terendahnya 66\% FEV1/FVCdan nilai tertingginya $100 \%$ FEV1/FVC. Analisis bivariat menunjukkan bahwa hasil analisis hubungan antara Kadar Debu Kayu dengan fungsi paru responden yang terpapar debu kayu di atas NAB mengalami gangguan fungsi paru sebanyak $24,3 \%$ dan $75,7 \%$ tidak mengalami gangguan fungsi paru. Tenaga kerja yang terpapar debu kayu di bawah NAB yang mengalami gangguan fungsi paru $18,2 \%$ dan $81,8 \%$ tidak mengalami gangguan fungsi paru. Berdasarkan beberapa penelitian yang telah dilakukan debu organik serbuk kayu memiliki dampak terjadinya penyakit paru obstruktif akibat kerja.

\section{Simpulan Dan Saran}

Debu organik serbuk kayu dapat menyebabkan terjadinya penyakit paru obstruktif pada pekerja yang terpapar debu tersebut. Tedapat penelitian yang mengatakan bahwa salah sau faktor terjadinya penyakit paru obstruktif akibat kerja dipengaruhi oleh banyakya kadar debu ditempat kerja serta lamanya paparan. Untuk itu penggunaan APD seperti masker harus diperhatikan pada saat bekerja.

\section{Daftar Rujukan}

American Thoracic Society. (1995). Standard for the diagnosis and care of patient with chronic obstructive pulmonary diseases (COPD) and asthma. Am. Rev. Respir Dis; 225-43.

Depkes RI. (2014). Parameter Pencemar Udara dan Dampaknya Terhadap Kesehatan.

Hicks GH. (2000). Ventilation. In:Cardiopulmonary Anatomy And Physiology. Philadelpia: W.B. Saunders Company. H. 311-37.

Ikawati Z. (2011). Penyakit sistem pernafasan dan tata laksana terapinya. Yogyakarta: Bursa Ilmu.

Irjayanti, A., Nurjazuli, \& Suwondo, A. (2012). Hubungan Kadar Debu Terhirup (Respirable) dengan Kapasitas Vital Paksa Paru pada Pekerja Mebel Kayu di Kota Jayapura. Jurnal Kesehatan Lingkungan Indonesia, 11(2), 182- 186.

Khumaidah. (2009). Analisis Faktor-Faktor yang Berhubungan dengan Gangguan Fungsi Paru pada Pekerja Mebel PT. Kota Jati Furnindo Desa Suwawal Kecamatan Mlonggo, Kabupaten Jepara. Tesis. Fakultas Kesehatan Masyarakat. Universitas Diponegoro.

Ma'rufi I. (2011). Mekanisme pneumonitis hypersensitif (HP) akibat pajanan debu penggilingan padi. Disertasi. Surabaya: Program Pascasarjana Universitas 
Airlangga.

Macnee, W. (2006). ABC Of Chronic Obstructive Pulmonary Disease. Pathology, Pathogenesis, and Pathophisiology. BMJ 2006: 332:1202-1204.

Mirza, S. (2010). Risks to The Health of Wood Workers: What Can Be Done. Zagazig Journal of Occupational Health and Safety, 3(1), 1-8 doi: 10.4314/zjohs.v3i.57945.

Mukono. (2003). Pencemaran Udara dan Pengaruhnya Terhadap Gangguan Saluran Pernapasan. Cetakan ke dua. Surabaya: Airlangga University Press.

Osman, E. \& Pala, K. (2009). Occupational Exposure to Wood Dust and Health Effects on The Respiratory System in A Minor Industrial Estate in Bursa/Turkey. International Journal of Occupational Medicine and Environmental Health, 22(1), 43-50.

Peraturan Menteri Tenaga Kerja dan Transmigrasi Nomor 13 Tahun 2011 tentang Nilai Ambang Batas Faktor Fisika dan Faktor Kimia di Tempat Kerja.

Sastrawijaya, A. T. (2009). Pencemaran Lingkungan. Cetakan ke tiga. Jakarta: Rineka Cipta.

Sholikhah, A M., Sudarmaji. (2015). Hubungan Karakteristik Pekerja Dan Kadar Debu Total Dengan Keluhan Pernapasan Pada Pekerja Industri Kayu X di Kabupaten Lumajang. Perspektif Jurnal Kesehatan Lingkungan. Vol 1 (1). : 1-12.

Sinaga., Meilyna, Jessika. (2019). Hubungan Kadar Debu Kayu di Tempat Kerja Dengan Faal Paru Sebelum, Saat Dan Sesudah Bekerja Pada Pekerja Industri Pengolahan Kayu Perusahaan X, Tanjung Morawa, Sumatera Utara. Fakultas Kedokteran Universitas Sumatera Utara.

Stephen, B.M., and yew S.K. (2008). Diagnosis of Chronic Pulmonary Disease. American Family Physician 78(1): 87-92.

Suma'mur, P. K. (2009). Higiene Perusahaan dan Kesehatan Kerja. Cetakan ke sembilan. Jakarta: CV Gunung Agung.

Suryani, M. (2005). Analisis Faktor Risiko Paparan Debu Kayu terhadap Gangguan Fungsi Paru pada Pekerja Industri Pengolahan Kayu PT. Surya Sindoro Sumbing Wood Industry Wonosobo. Tesis. Fakultas Kesehatan Masyarakat. Universitas Diponegoro. Semarang.

Suryani, Meta., Setiani, Onny., Nurjazuli. (2005). Analisis Faktor Resiko Papaan Debu Kayu Terhadap Gangguan Fungsi Paru Pada Pekerja Industri Pengolahan Kayu PT Surya Sindoro Sumbing Wood Industry Wonosobo. J Kesehat Lingkung Indones. Vol. 4 (1).

Tanko Y. (2011). Effect of dust on cardiopulmonary function and anthropometric parameters of carpenters and non-carpenters in Sabon Gari local government area, Kaduna State, Nigeria. Asian Journal of Medical Science. 3:43-46.

Wardhana, W. A. (2004). Dampak Pencemaran Lingkungan. Cetakan ke tiga. Yogyakarta: Penerbit Andi. 